\title{
THE STUDY OF THE MULTIFACTORIAL INTRODUCTION OF DEPOSIT INSURANCE PRICING
}

\section{ZHAO MINGQING and LIU HAIMEI}

Shandong University of Science and Technology

College of Mathematics and Systems Science

Shandong, Qingdao, 266590

P. R. China

e-mail: zhaomq64@163.com

\begin{abstract}
The deposit insurance pricing is the core of the deposit insurance system, establishing the extent of participation in the deposit insurance system and deposit-taking financial institutions depend on determining premium rates. The three parameters' introduction of regulatory forbearance, uninsured deposits and income tax, expanding the deposit insurance Merton pricing model. Selected domestic three banks are to estimate their insurance rates, and there are some differences between the resulting premium rates, indicating China for risk rates, and the introduction of income tax to expand deposit insurance pricing model can significantly reduce premium rates.
\end{abstract}

\section{Introduction}

Deposit insurance system [1] is a financial security system, which refers to the establishment of an insurance agency in the financial system. The banks and other deposit-taking financial institutions are taken as the insured and the insured deposits are taken as the object of insurance. When deposits of financial institutions have payment

2010 Mathematics Subject Classification: 91Bxx, 91B30, 97M30.

Keywords and phrases: deposit insurance pricing, regulatory forbearance, uninsured deposits, income tax.

Received January 16, 2015

(C) 2015 Scientific Advances Publishers 
difficulties or loss of liquidity, insurers need to provide insured depository institutions with funding assistance or claims based on insurance contract to maintain a healthy and stable financial system in the form of a loan insurance the social security system in order to protect the legitimate interests of some or all of the creditors.

Currently, there are 95 countries in the world, which have established a deposit insurance system, and there are more than 20 countries are studying and preparation. Our country has began to put forward the establishment of the deposit protection fund to protect the public interest in "Decision of the State Council on Financial Reform" for the first time since 1993. Until May 2013, People's Bank of China issued the "China Financial Stability Report in 2013", which proposed that deposit insurance system was an important part of the financial system and it was important to push forward the construction of the deposit insurance system. China's deposit insurance system has been in the brewing. Today, our country implements implicit deposit insurance system on the banks. With the continuous improvement of financial markets, China's transition to explicit deposit insurance system is imperative. Whether deposit-taking financial institution was insured voluntarily or forcibly, the core of the smooth implementation of the deposit insurance system is determined by the deposit insurance premium rates. The design of premium structure will influence the acceptability to deposit insurance system on the insured bank in a large extent. Appropriate and reasonable premium structure helps to reduce adverse selection and moral hazard and promote insurance products of deposit insurance agency that is designed to attract deposits insured financial institutions.

For the determination of deposit premium rate, there are three main research directions as follows in the current literature. Firstly, there is the expansion of Merton option pricing model. Many domestic scholars were based on researches conducted by Merton model, for example, Jinbao and Ruoen [2] have introduced regulatory forbearance, and come to the deposit insurance pricing formulas and the illustration. Jinbao and 
Ruoen [3] have introduced uninsured deposit rate, and discussed the effects of uninsured deposit rate on deposit insurance pricing formula. Xingkun and Jian [4] have proposed Merton deposit insurance pricing model under the condition of tax incomes. Secondly, there is the expected loss pricing model. Such as, Zhihong [5] thought that Merton option pricing model had some limitations in terms of the market economy, and has discussed the expected loss pricing model with the introduction of expected default probability and loss given default probability. Thirdly, there is the pricing model based on GARCH model. Such as, Chunhai and Lili [6] has studied the deposit insurance premium rate of China's major commercial bank with the use of GARCH $(1,1)$ model. Many studies were based on Merton option pricing model both in theory and practice, and mainly because the introduction of regulatory forbearance or uninsured deposit or tax incomes makes Merton model closer to reality, but there is no taken in account of these three factors at the same time. The deposit insurance pricing model will be more realistic when considering these three factors. In this paper, we will generalized Merton deposit insurance pricing model with the introduction of regulatory forbearance, uninsured deposit and tax incomes at the same time. And we conduced empirical research to Industrial and Commercial Bank of China, China Construction Bank, Bank of China and Agricultural Bank of China.

\section{Merton Deposit Insurance Pricing Model}

Merton [7] considered that deposit insurance was seen as the deposit insurance agency to sell insurance to the insured bank with a put option, which gives the right of a certain sale price to bank managers in the maturity date. Merton corresponded value of bank assets to the stock price and corresponded the exercise to the debt and all bank liabilities were from banking deposits.

Assumptions: (1) bank deposits equal to its liabilities, and the principal and interest are insured; (2) from the next annual review of the bank's time is equal to the maturity date from the time; the value of assets; and (3) bank obey geometry Brownian motion: 


$$
d \ln V=\mu d t+\sigma d z
$$

where $V$ is the value of bank assets of the time $T ; \mu$ is the expected return of assets; $\sigma$ is the standard deviation of asset returns; and $z$ obeys the standard Brownian process.

Due to the same principle between put option with deposit insurance, we can obtain the value of deposit insurance based on Black-Scholes option pricing model

$$
D=B e^{-r T} F\left(\chi_{2}\right)-V F\left(\chi_{1}\right)
$$

where

$$
\chi_{1}=\frac{\ln (B / V)-\left(r+\sigma^{2} / 2\right) T}{\sigma \sqrt{T}}, \chi_{2}=\frac{\ln (B / V)-\left(r-\sigma^{2} / 2\right) T}{\sigma \sqrt{T}},
$$

where $D$ is deposit insurance premiums; $B$ is bank debt at expiration; $r$ is the risk-free rate; and $F(\bullet)$ is the standard normal distribution function.

Further assume that deposit insurance $B$ is risk-free, and its present value is

$$
M=B e^{-r T}
$$

Let $m=D / M$, then $m$ expresses the insured deposit warranty cost per unit of RMB. According to Equation (3) and Equation (4), $m$ can be expressed as

$$
m(c, \tau)=F\left(l_{2}\right)-\frac{1}{c} F\left(l_{1}\right)
$$

where

$$
l_{1}=\frac{\ln (c)-\tau / 2}{\sqrt{\tau}}, \quad l_{2}=\frac{\ln (c)+\sqrt{\tau} / 2}{\sqrt{\tau}},
$$

$c=M / V$ indicates the ratio of deposit and asset value of insured bank; $\tau=\sigma^{2} T$ indicates the variance of return rate of bank asset during the insured period. 
THE STUDY OF THE MULTIFACTORIAL INTRODUCTION $\ldots \quad 71$

\section{Generalization of Merton Deposit Insurance Pricing Model}

There are many strong limitations in practical application because Merton deposit insurance pricing model did not consider some practical factors, which is embodied in the following two aspects. Firstly, the deposit insurance is prone to moral hazard because there is asymmetric information among of the deposit insurance agency, depositors and banks. Secondly, the impact of tax law on cash flow is more and more attention in the modern organization, and a particular cash flow is deducted in tax or pre-tax or the difference of tax rate has important implications for corporate decision-making. The key to solving these two problems is to the introduction of regulatory forbearance, uninsured deposit and tax incomes in Merton pricing model.

In this paper, we will firstly introduce regulatory forbearance and uninsured deposit into deposit insurance pricing model, then introduce tax incomes on this basis, and comprehensively come to deposit insurance pricing model formula with these three parameters.

Implementation of regulatory forbearance can effectively encourage bank managers to avoid high-risk business, and also avoid premature liquidation of commercial banks. Regulatory forbearance can minimize the impact of the commercial banks bankruptcy to the financial system while it can protect the interests of deposits. This is consistent with the deposit insurance system to the purpose of maintaining the interests of deposits, financial security, and stability. For the consideration of regulators, the insurance agency is not only not immediately liquidate the bank but also will direct injection of funds or suspend close when it finds the bank's asset value $V$ is less than the total debt $B$. Assumed the closed rule is $V \leq \rho B$, which $\rho$ is the regulatory forbearance parameter and represents a scaling factor of bank debt. Clearly, $\rho=1$ is in the case of the insurer not to implement the policy of forbearance. But after considering the regulatory forbearance, the insurance agency will inject capital $B-V$ to bank if the value of the bank's asset is between $\rho B$ and $B$. 
In practice, in order to strengthen financial market discipline to play a supervisory role of commercial banks for large deposits, deposit insurance agency will impose a quota underwriting on commercial banks. As a result of payment limits of the deposit insurance system, deposit insurance will not protect the excess when depositors amount exceeds the insured limits. When the implementation of part of the deposit insurance, on the exceeded part of the deposit insurance limit depositors necessary requirement to obtain risk-reward, while competitive pressures may prompt commercial banks to raise uninsured deposit insurance is within the allowed range of policies that can effectively encourage depositors and deposit insurance to monitor. There for, the debt of banks can be divided into two parts, including deposit insurance with representation of $B_{0}$ and uninsured deposits indicated by $B_{1}$. When the contract expiration date comes, all of the banks liabilities will be

$$
B=B_{0}+B_{1} .
$$

Insured depositors 'available value of the assets is

$$
V_{B_{0}}=\frac{B_{0}}{B_{0}+B_{1}} V
$$

Therefore, the deposit insurance agency should pay amount

$$
f(V, T)=B_{0}-\frac{B_{0}}{B_{0}+B_{1}} V .
$$

In summary, when the contract expiration date comes, the deposit insurer's payment function is

$$
f(V, T)= \begin{cases}B_{0}-\frac{1}{1+\beta} V, & \frac{1}{1+\beta} V \leq \rho B_{0} \\ 0, & \text { otherwise, }\end{cases}
$$

where $\beta=\frac{B_{1}}{B_{0}}$.

Let $\xi=\frac{1}{1+\beta}$, and according to Ito differential rule shows that $\xi V$ still follows the geometric Brownian motion. Combined with Black- 
Scholes option pricing formula and ideas of Merton pricing model, we can obtain the following deposit insurance pricing formula with the introduction of regulatory forbearance and uninsured deposits is

$$
P=\rho B_{0} e^{-r T} F\left(-\chi_{2}\right)-\xi V F\left(-\chi_{1}\right)
$$

where

$$
\chi_{1}=\frac{\ln \left(\xi V / \rho B_{0}\right)+(r T+\sqrt{\tau} / 2)}{\sqrt{\tau}}, \quad \chi_{2}=\frac{\ln \left(\xi V / \rho B_{0}\right)+(r T-\sqrt{\tau} / 2)}{\sqrt{\tau}} .
$$

Deposit-taking financial institutions to buy insurance is not for reasonable avoidance of tax, but tax shield effect does affect the reasonable determination of the deposit insurance premium and will affect the premium range acceptable to both parties. For insurance applicant, assuming that the tax law of deposit insurance premiums $P$ may be deducted before tax, the insured deposit-taking financial institutions will save taxes $P T_{B}$, where $T_{B}$ is the income tax of insured bank, and $0<T_{B}<1$. Therefore, after considering the effect of income tax, the insured actually paid premium is $P\left(1-T_{B}\right)$, which is less than $P$ that is not considering the tax rate.

Therefore, from the standpoint of the insured bank, the deposit insurance pricing formulas is

$$
\begin{aligned}
N & =P\left(1-T_{B}\right) \\
& =\left[\rho B_{0} e^{-r T} F\left(-\chi_{2}\right)-\xi \operatorname{VF}\left(-\chi_{1}\right)\right]\left(1-T_{B}\right) .
\end{aligned}
$$

Sum up, that is the deposit insurance premium with the introduction of regulatory forbearance, uninsured deposit and tax incomes and the deposit insurance premium of the unit RMB is calculated as

$$
g=N / B_{0} e^{-r T}
$$

We take Equation (10) into (11), the deposit insurance pricing formulas is

$$
g=\left[\rho F\left(-\chi_{2}\right)-\frac{\xi V}{B_{0} e^{-r T}} F\left(-\chi_{1}\right)\right]\left(1-T_{B}\right) .
$$




\section{Empirical Analysis}

In the calculation of the deposit insurance premium, a crucial step is to calculate the volatility of bank assets. We calculate the volatility of bank assets with annual total market capitalization data of stocks of Industrial and Commercial Bank of China, China Construction Bank, Bank of China and Agricultural Bank of China in 2011 in this paper. Let $u_{i}=\ln \frac{S_{i}}{S_{i-1}}$, where $S_{i}$ is the observed stock prices of the $i$-th day, then day volatility of the insured bank assets is $S_{0}=\sqrt{\frac{1}{n-1} \sum_{i=1}^{n} u_{i}^{2}-\frac{1}{n(n-1)}\left(\sum_{i=1}^{n} u_{i}\right)^{2}}$. Volatility in earnings is $\sigma_{e}=S_{0} \sqrt{241}$ (where 241 is the number of days in a year after the removal of legal holidays). According to Ito' lemma, we can know $\sigma=\frac{\sigma_{e}}{V F\left(-\chi_{2}\right)}$, where $\sigma_{e}$ is the standard deviation of return on equity and $\sigma$ is the standard deviation of return on assets.

We calculated the premium rate $(g)$ of deposit insurance pricing model based on regulatory forbearance and uninsured deposit and the premium rate $\left(g^{\prime}\right)$ of considering of income tax, and the results are shown in Table 1.

Table 1. Premium rate of deposit insurance (unit: million)

\begin{tabular}{lcccrrc}
\hline Bank name & $G$ & $B$ & $V$ & $\sigma$ & $g$ & $g^{\prime}$ \\
\hline ICBC & 12261219 & 12690362 & 15476868 & 11.08 & 0.069 & 0.065 \\
CCB & 9987450 & 10337011 & 12281834 & 11.08 & 0.138 & 0.136 \\
BC & 8817961 & 9126590 & 11830066 & 10.06 & 0.005 & 0.004 \\
ABC & 9622026 & 9958797 & 11677577 & 11.73 & 0.251 & 0.248 \\
\hline
\end{tabular}

As can be seen from Table 1, firstly, the different banks has different deposit insurance rate premium so that Chinese bank is more suitable for risk rate. If the premium rates of different bank deposits are the same, then the bank expects to increase spreads through high-risk loan 
program can not absorb more deposits based on increased spreads. Although this increase the risk of insurance agencies and uninsured deposits, there has been no loss, which will encourage the motivation of banks to engage in high-risk business and be prone to moral hazard. But the risk rate just overcome this shortcoming. Secondly, the deposit insurance premium out of consideration of the income tax rate is significantly higher than the deposit insurance premium of considering the income tax rate, which can be seen the impact of the tax shield effect. Based on the consideration of insured banks, it will be in favour of initiative of insured bank if the deposit insurance premium rate decline.

\section{Conclusion}

This article concludes the deposit insurance pricing model with the introduction of regulatory forbearance, uninsured deposit and tax incomes based on the Merton deposit insurance pricing model, and this article has empirical analysis of selecting Industrial and Commercial Bank of China, China Construction Bank, Bank of China, and Agricultural Bank of China. The result shows that there is a difference between insurance premium so that China is suitable for risk rates. Under the guarantee of deposit insurance company earnings, the lower premium expenditure of depository institutions will attract more banks to participate in insurance.

\section{References}

[1] Zhang Yatao, The study of deposit insurance pricing model, International Financial Research 11 (2003), 35-38.

[2] Zhang Jinbao and Ren Ruoen, The study of deposit insurance pricing under the condition of regulatory forbearance, Shanxi Finance and Economics University 28(2) (2006), 95-98.

[3] Zhang Jinbao and Ren Ruoen, The study of deposit insurance pricing under the condition of uninsured deposit, Systems Engineering 25(4) (2007), 88-91. 
[4] Jiang Xingkun and Sun Jian, The study of Merton deposit insurance pricing model with the introduction of income tax, Statistics \& Information Forum 28(3) (2013), 22-27.

[5] Wei Zhihong, The study of deposit insurance of China, Financial Research 5 (2004), 99-105.

[6] Zhang Chunhai and Zheng Lili, An empirical study on commercial bank deposit insurance option pricing - Based on the comparison and analysis Merton, RV and GARCH model, Scientific Decision 5 (2011), 82-94.

[7] R. C. Merton, An analytic derivation of the cost of deposit insurance and loan guarantee, Journal of Banking and Finance 35(1) (1997), 3-11.

[8] P. W. Dong, X. Z. Zhang and X. Yao, Study of deposit insurance pricing model for list banks in China based on RV method, International Conference on Management Science \& Engineering 19 (2008), 1301-1305. 